\title{
Cultural Quality Revitalization Model in Strengthening The Higher Education Capacity Building 'Good Learning Culture'
}

\author{
Syarifuddin Achmad \\ Fakultas Sastra dan Budaya \\ Universitas Negeri Gorontalo (UNG) \\ Gorontalo, Indonesia \\ syarifuddinachmad12@yahoo.com
}

\author{
Syamsu Qamar Badu \\ Fakultas Matematika dan IPA \\ Universitas Negeri Gorontalo (UNG) \\ Gorontalo, Indonesia \\ syamsu@ung.ac.id
}

\begin{abstract}
- this paper is to present the result of research as a best practice in promoting Universitas Negeri Gorontalo, as a Higher Education, for strengthening its Capacity Building. This research has successfully formulated a Cultural Quality Revitalization Model 'good learning culture' in overcoming the lack of quality assurance management implementation, and the insufficient staffs' insight and behavior on academic quality treatment. The domains innovated in building up model system consists of conceptual and procedural model. The method used in enforcing that model is Focus Group Discussion (FGD) strategy. In conceptual system, some dimensions have been successfully treated, namely: (a) Strategy of achieving vision, mission, aims, and target of institution; (b) Strengthening a good governance; (c) Developing the students' in academic affairs; (d) Updating curriculum and teaching; (e ) Empowering human resources development; (f) Optimizing research, society service, and networking; (g) Effectively utilizing Infrastructure, equipment and ICT. In Procedural model system, it has formulated internal quality assurance system; while producing some quality assurance documents, such as: (1) Instrument of quality culture; (2) Internal Self Evaluation guide book; (3) quality policies guide: (4) Quality management plan; (5) Academic audit guide book. This study is expected strengthening the Capacity Building of Higher Education Institution.
\end{abstract}

Keywords-revitalization system, quality culture, conceptual, Model, institution, management

\section{INTRODUCTION}

Quality Culture is a postulate to measure a Higher Education Capacity Building in global area. That's way it is determined by how the community members of Higher Education institution to act the quality culture development from period to period. In other words, implementing a continuous quality management needs intervention and assessment systematically and comprehensively [1]. In this study, we call it as Cultural quality revitalization. There are two factors relate to 'Quality Culture', namely: (a) Conceptual Model, (b) Procedural Model In this context argued in a organization needs ogranizational culture to control mechanism through its norms, serves as a control mechanism to change behaviors from undesired to desired behaviors [2]. Organizational culture means a pattern of behavioral norms that are adopted in solving problems faced. Organization's internal environment is represented by its culture [3], [4].

Conceptual Model is to review the theoretical concepts, concerning to the quality culture in managing and fostering well academic atmosphere behavior, by regulating the academic component function as a unit system, including to apply the cultural principles, that leading the community members of university to build up national competitiveness as a postulate enlarging their quality culture insights [5].

Thus, procedural model is a creating system in implementing the academic quality assurance based on the regulated, systematic and comprehensive phases and steps that so make it easy to be evaluated [6]. So, it needs to be accomplished by manual document, procedure document, form and instructional job document, and operational procedural standard document for building up and sustaining a well academic affair in university and study program.

Based on the strategic plan of Universitas Negeri Gorontalo (UNG) in the period of 2018-2035; including the achievement of the vision and mission, UNG tries to create the quality assurance document, such as Grand Strategic Plan Document, The Strategic Plan in 4 years phase Document, and Quality Policy Document, and Operational Plan for One Year Document, with completing and supporting other important document, such as manual, operational procedure document, and other important document which being relevant with the internal academic quality assurance. The question appeared is how is the synergist of those documents being addressed as a culture and academic behavior of university and faculty members of UNG? Based on that question, this study presents the concept not only the conceptual model but also the procedural model related to the quality assurance [7].

\section{ACADEMIC QUALITY STANDARDIZATION}

Optimizing the academic culture as behavior for the academic staffs in Higher Education institution is concerning two quality targets. These two targets is reflection object of continuous improvement, namely: (1) Quality Management Dimensioned, (2) Quality Behavior Dimension. Both dimensions are being symbiosis each other in achieving the 
quality maximum [8]. To discuss about quality management is tightly related to the setting of an organization system; starting from the quality target plan, the process of activities or the programs that have been determined, until evaluation and monitoring of quality achievement, which being reported as an accountability of academic performance [9], [3].

Thus, quality behavior of academic staff is responsibility that showing in carrying out the quality plan or it can be stated as a commitment and consistency which being reflected as a self-responsibility [10]. It is necessary to develop human resource capacity in fulfilling organizational sustainability and professional demonstrating to maintain the institution competes in the future [10], [11]

The quality academic standard is based on the national education quality standard as what had been formulated by National Accreditation Board of Higher Education [9], [12]. Accordingly, there are seven quality assessments that have been formulated in treating the academic quality. Those are (1) the effort attitude in developing quality which being related to vision and mission achievement, including to aims, target, and strategy used achieving the target that have been determined; (2) the effort attitude in holding organization governance structure to be effective, responsible, accountable, fair and credible; (3) the effort attitude in developing quality service to students and alumnae; (4) the effort attitude to the human resource; (5) the effort attitude towards curriculum development and adaptive learning accordance to the competencies needed by job industries; (6) the effort attitude towards the infrastructure and equipment quality in relating to the quality and quantity supporting the excellent service and the ease of accessibility towards stakeholders; (7) the effort attitude to improve the quality and the quantity of researches and social services, and improving networking to cross partnership institution whether in home or foreign country; related to the nation competitiveness.

Before this study implemented, most of academic staffs, even faculty members do not yet realize the importance of the internal quality management assurance to be implemented better. Based on data acquired from the Quality Assurance Board (QAB) of UNG (2015), that around $45 \%$ Study Programs having lower level of accreditation status (C mark). The lower accreditation status score of several study programs were triggered by several cases. Some of them are insufficient knowledge and less insight of academic staff and faculty members about the quality assurance procedures. This case will affect their behavior in organizing well the quality management of their units or institutions. The other case is the incompleteness or inadequacy some documents of quality assurances that supporting academic quality management. So, it is quite difficult to justify quality positioning, because of unavailable assessment of performance and achievement through the periodic monitoring and evaluation of academic quality in this institution.

Reflecting and overcoming the problems found, as what have been elaborated, this study offering solution through an action and descriptive research. The main focuses of this study coverage the human resource insight, attitude, behavior and responsibility concerning to quality management; the other focus is treatment of quality management in the field, based on conceptual and procedural model. The fusion of two models bring forth a revitalization model of treating an academic quality culture in supporting this institution effectively achieves vision as 'a Leading University' in South Asia in the earlier year of 2035. The implementation of this study impacts the strength of institution capacity building as a Competitive Higher Education.

The other finding is to display a comprehensive model which being attached in this paper that describing the cultural quality revitalization model as Good Learning Culture' in strengthening the Higher Education Capacity Building. That means the academic system needs reflection periodically as an improvement of quality system and behavior cultural quality supporting institution to achieve its vision target.

\section{MANAGEMENT OF ACADEMIC QUALITY}

The health Organization can be recognized by its program run well, systemic, hierarchically, systematically, measurably. That condition will be a basic for reflecting cultural development and quality behavior in strengthening the capacity building of institution. The institution which having a well-health organization, will have a strong and reliable competitiveness power [13]. So, it is quite reasonable to reform and to develop the mode of cultural quality behavior among the academic staffs.

It is stated [9] that there are two things should be created in building up the cultural quality behavior towards the academic staffs; firstly, developing the competitive management system professionally. That will be base for measuring and reflecting and accelerating gradually the quality achievement maximally. Secondly is strengthening consistency and commitment behavior in implementing the academic quality assurance; as a maximal quality achievement base, especially teaching process [14]. Based on that two cases presented, it is reasonable, to reform of quality assurance implementation in Higher Education, including to UNG institution. Based on the above arguments, this study is focused on developing model and revitalization of quality culture, as ' $\boldsymbol{A}$ good learning culture at $U N G$ ' in rising up the academic quality assurance.

From the focus stated, this study aims at upgrading the accreditation status of study programs, as what the Board of Academic Quality Assurance reported in the year 2015 that most of study programs in this institution, around $45 \%$, got low score on their accreditation. The root of this problem is because of being low quality culture of academic staffs to treat the academic quality. So, the aim of this study is expected to overcome the lower academic quality culture of staffs. In increasing the quality academic culture of staffs member, there are two dimensions, namely: (a) Quality management system; (b) Self-behavior on developing quality culture for staff members at Study Programs in UNG.

Quality Management System is related to arrange the academic administration of data management, which being not only through on-line but also off-line. The data base acquired for implementing quality management system in all levels and all academic implementing units are strengthening the quality 
assurance systems [15],[16]. The embodiment of quality assurance system is a manifest of developing capacity building of Higher Education, including to UNG. While, Self-behavior Arrangement, in the context of developing quality culture is related to self-development to rise up self-esteems and selfexistence through efforts of enlarging professional insight and science responsibility, building up Self-commitment, consistency also developing self-driven [17]. It means that the output is going to be achieved in this research consists of firstly the improvement of quality management to all academic levels and units in UNG; Secondly is the development of human resources for strengthening quality managements [13]. So, it needs a frequent reflection for gaining better academic quality of institution 'Good learning culture'.

\section{THE INDICATORS OF WELL CULTURAL \\ QUALITY DEVELOPMENT}

The indicators of the organization which having a well quality culture, it can be reflected on behavior attitude of staff members of institutions [7]. Some indicators well cultural quality [18]. as in: (1) Its orientation is on stakeholders' satisfactory; (2) Continues reflection and improvement obsession; (3) Having a sincere desire towards input ideas or suggestion and feedback; (4) Using a team work approach in overcoming the problems and handling process; (5) The internal partnership is supporting one each other; (6) The team works should be recognized as partnership and internal customers; (7) involving and delegating broadly the staffs members in handling jobs; (8) Preparing training and education for the staffs members in upgrading their quality and qualification more professional at all levels; (9) Choosing and determining a high quality standardization; (10) Appreciating the performance for the work achievement obtained.

Building up cultural academic quality is as like as building up a construction. As building up management of the cultural academic quality, it should start to improve understanding to the rule of organization changes, such as (a) keeping attention to the internal and external condition of institution, (b) involving all people, who will be as subject to change it [19].

Based on the descriptions above, the indicators that will be developed in the cultural academic quality can be elaborated as follows.

1. Arranging the organization management system more effectively and efficiently achieving the institution goals.

2. Creating mutual communication, synchronizing, and tightly correlating and relating among the team works from sub-divisions, as a harmony system, that being guided by the standardization of operational procedure.

3. Forming well working academic atmosphere through periodical reflecting strategy, and emphasizing on the quality output and outcomes development.

4. Fostering development efforts and self-professionally guided towards tasks and responsibility, as a commitment and consistency in achieving organization goals or future vision.
5. Assessing and evaluating the achievement performances, as an accountability report periodically and systematically; and also to be a developmental reflection function.

6. Obtaining stakeholders' satisfactory reflection for carrying out an excellent service performance; while having an open asses to maintain a credibility and reflecting accountability[20].

Those indicators above become postulate resource that can be used in carrying out this study. Certainly, those indicators will be having a role to create a condition of developing model and cultural quality revitalization for academic staff members (as stated in grand plan of UNG: 2014) [21]. That case is an effort to develop the capacity building of Higher Education institution. In this context, several of previous researchers are focusing the study on the academic quality systems, as a study which being carried in the year 2012 [20], and in the year 2014 [21]. However in the year 2016 , back to investigate the academic quality, by promoting the research topic concerning to 'Developmental Model and Cultural Quality Revitalization 'Good Learning Culture'. Research mapping of cultural quality system can be drawing on the following diagram.

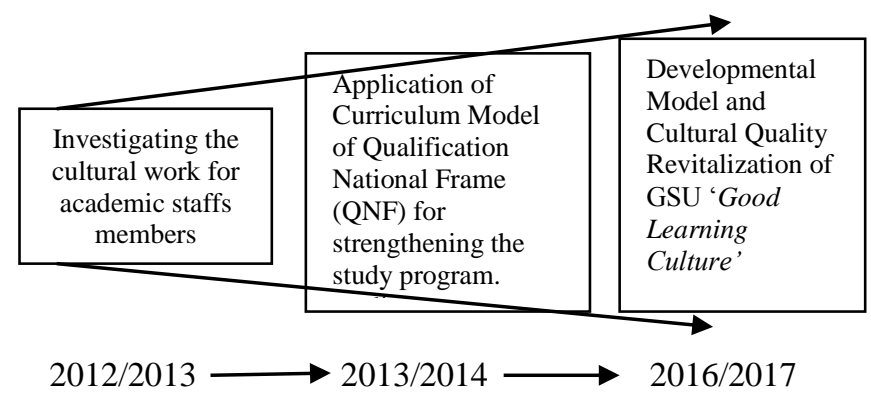

Fig 1. Road Map Research on Developing Quality Culture of Staff Academic Members UNG

\section{DEVELOPING MODEL AND CULTURAL QUALITY REVITALIZATION}

The phases of implementing analysis for creating developing model, it can be based on three cases. Those are: (a) Input, (b) Process, and (c) Output. However in this research analysis, it is also calculated the outcomes achieved, after that system has being implemented. Those predictors can be elaborated, as follows.

\section{A. Input}

The row inputs that will be analyzed in this study are all the academic parameters based on the accreditation phases coverage. In this context, it can classified as in: (a) vision and leadership management, (b) students and alumni, (c) academic human resource, (d) curriculum and learning-teaching process, (e) facilities, infrastructure, cost-budgeting, and information technology, (f) output of research, social service and partnership net-working. It is argued that those components can be a set of input analysis base for creating the academic cultural quality revitalization model [21]. The realization may 
be treated on the institution self-evaluation of institution. Selfevaluation of institution is an effective strategy forming academic cultural quality, that useful to upgrading and accelerating the quality assurance.

\section{B. Process}

Some activities to revitalize the cultural quality of academic staff's members; these are (1) creating the instrument of SWOT Analysis: in surveying and investigating the strength potentiality, weakness, opportunity, and the treat; (2) carrying out depth analysis, by evaluating attitude behavior development towards academic cultural quality; (3) constructing a set of behavior cultural quality instruments based on professional development and academic quality standardization; (4) Setting up the developing design model and revitalization cultural academic quality; (5) Disseminating and reflecting developmental model and revitalizing the cultural quality; (6) Implementation of developmental model and cultural academic quality behavior, by utilizing the system design created through treatment and action research.

Those process steps will foster the academic culture tradition for staff members, which emphasizing on the quality assurance as well as possible. And this context crystalizes the revitalization of cultural academic quality; because of using clinical supervision and lesson study strategy. Based on this strategy, the quality can be reflected and upgraded based on data acquired through self-evaluation analysis. The applications of this principle, the quality assurance can be guaranteed effectively achieve objections of academic quality, based on data identified, presented, and discussed [21].

\section{Output, Outcomes and Impact}

The output and outcomes that have been achieved, coverage several targets aimed, those are: (1) Being created the instrument survey; (2) Being constructed the Standard of Operational Procedure of academic quality and manual document: (3) Being set of a quality evaluation and assessment instrument, (4) Being designed developmental model and cultural academic quality behavior for academic staff members 'Good Learning Culture'. Thus, the outcomes of this study achieved consists of: (1) Being implemented the revitalization of cultural academic quality model for the staff members of UNG; (2) Being ready supporting by the quality documents, such as Standard Operational Procedure, Quality Manual, and Management Quality Academic Policy [22].

The impact of this study interaction is to form a creative attitude in accelerating well-academic atmosphere by emphasizing the academic quality. Based on the outputs, outcomes and impact achievement of this study, it will support UNG institution in achieving its vision and mission as 'Leading University'. So, successful achievement of this research implementation will grade up this institution quality more capable to gain its capacity building. By having the quality culture will improve the health institution, because the staff members will foster the norms of behavior value, which being responsible to the success of institution organization [23], [16]

\section{METHOD OF RESEARCH}

This study used Research and Development (R \& D) Approach in developing model of cultural quality revitalization in strengthening the institution achieving its capacity building 'Good Learning Culture'. Its steps can be elaborated as follows:

1) Carrying out study of theoretical Concept: The result of theoretical concept study will be based on designing model of cultural quality revitalization, and also as based on constructing the quality management instrument survey. Including as based on some documents that supporting the implementation internal quality management assurance, such as SOP, quality policy, manual of quality implementation.

2) Survey on environment of academic atmosphere: Some predictors will be investigated on the field, such as motivation resources, inspiration, mind-set, in developing cultural quality behavior, for academic staff members in all units' level: from Unit Implementation Programs, Study Program, Faculty, Institutions, until University level. In this context, the category that being investigated consists of (a) quality potentiality identification, (b) cases treat the academic quality, (c) developing quality strategy.

3) Collecting data: In this study, it is used 3 techniques, for collecting data, firstly distributing questionnaire (research instrument) to acquire the research target data; secondly using interview based on the management academic parameters, as a key for developing academic quality; thirdly applying Focus Group Discussion (FGD) in constructing frame of developing quality model and revitalization of cultural academic quality by utilization of Kaizen / Continuous Improvement Strategy as drawn below:

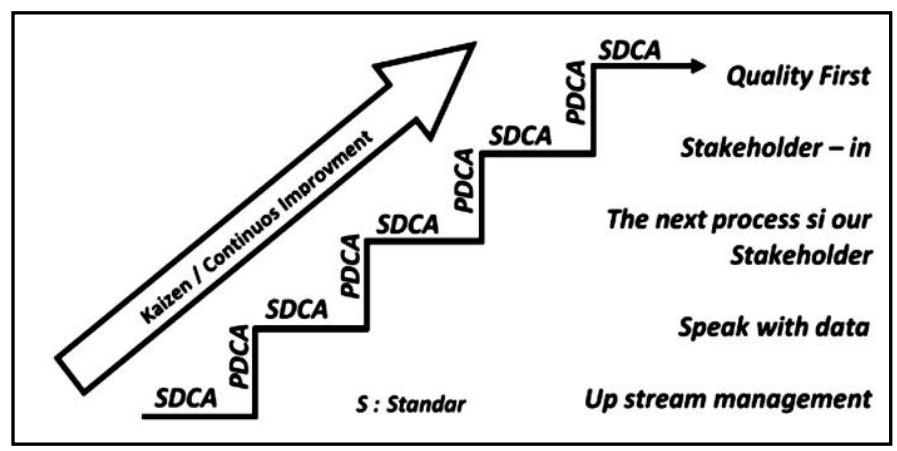

Fig 2. Kaizen Concept

\section{Adapted from Kaizen Concept: Masaaki Kaizen 1999}

\section{RESEARCH FINDINGS AND DISCUSSION}

Based on the conceptual study and the field investigation that have done in this research, it is found seven dimensions as a media for assessing the quality, as well as to treat the cultural quality behavior and academic quality management. The elaborations of each dimension can be presented as follows:

Firstly, is being related to the vision, mission and goal of institution. The health of Higher Education management is 
starting from the successfulness of formulating vision, mission and goal. The role of that is a guide for accelerating quality culture and to revitalize all units of institution organization. That's way the vision, mission and goals of institution should be realistic and clear steps for achieving the goals as in the periodically millstones. The gradual achievement based on time scale can be measured as well as possible through the key performances indicators. Before this research treatment done, it is found that this dimension has not yet considered and implemented systematically and comprehensively. However while this study is treating, the human resource of this institution realizes and willing to reform the vision, mission and goals of each unit of this institution. The application of cultural quality revitalization model can change the insight of staff members of each unit, by emphasizing the quality treatment. This action not only changes the quality management physically, but also behavior and cultural quality among the academic staffs and faculty members or lecturers.

Secondly, is being related to leadership and organization. The quality and well management indictors can be recognized by three parameters: (a) having five principles that can be reflected, namely, credibility, transparent, accountability, responsibility in developing policy and human resource, consistency in implementing vision and mission; (b) In building up a good governance of academic management, the policy of decision makers in that unit or institution are able to empowering management systems, as based on the implemented role. The good governance of management can form well-administration system function, in keeping affectivity, efficiency and productivity in efforts to manifesting vision and mission, including strategy achieving the targets by strengthening the integrity of institution or working unit. So, the implementation a good government in an institution or working unit can be reflected by planning, staff development management, staffing, and supervising, assessing and evaluating; (c) having quality assurance management institution that having responsibility to arrange and to evaluate the strategy achievement targets, the procedure quality standardizations, mechanism implementation programs, human and non-human resource, information activity system. Evaluation result is being well formulated, broadly communicated, and comprehensively implemented as reflected program in accelerating academic quality assurance more effectively.

Thirdly, related to Curriculum design, learning and teaching dimension consists of: (a) the Curriculum designed and implemented is expected to guaranty achieving the aims of institution or Study Program mission and vision [21][24]. In that curriculum, it should be prepared the optional subjects to cope the alternative competencies based on the learners' interest, in order strengthening their aptitude on science development. In learning and teaching process, it should be guaranteed the learners acquire the competencies as what have been described on the curriculum; (b) Leaning system built based on the relevant plan, learning objective domain such as cognitive, skills and behavior as hierarchically. Learning activities is a set of learning experiences acquired that forming competencies around learning objectives domain based on learning activities such as lecturing, practicum, training, workshop, and working attachment, completing learning tasks. (c) Learning achievement evaluation, all learning objectives domain are evaluated objective, transparent, and accountable, by using a valid and reliable instrument or test, and also used norm criterion. Learning achievement evaluation is utilized to measure the students' academic achievement and giving a feedback to the process of teaching and learning activities [25], [26].

Fourthly, related to the quality of research as a main task of Higher Education, in giving contribution and utilizing benefit towards quality development of learning process, science and technology development, and also upgrading the social life index. So, operationally some predictors of culture and quality assurance of research, consists of (1) the adequate human resource readiness from the academic staff members, (2) the result of research strongly related to the sciences development that being educated by Study Program, (3) having an impact power towards the science and industry development, (4) it has proportional and equal distribution among academic staffs based on the adequate varied research skim, which not only offer budget from the internal but also from external higher education (including UNG); (5) Collaborative research by involving the Higher Education Leaners, as lesson learned; (6) Being disseminated research results that accelerating the access of research information and strengthening science and technology; (7) The output, and outcomes can be utilized to increase well-academic atmosphere impact, and also and manifesting in job industry; (8) the realization of good governance and leadership support cultural research, as matter of fact in UNG begins to grow up that building up its capacity building. That is related what have been argued that the capacity building of Higher Education can be strengthened by its research achievement and how the impact power influences the science and technology development [13].

Fifthly, related to the social services. The realization of social service is the shape of expert contribution or science technology transfer that can be utilized to grade up social welfare. That's way the better of social service, if it really has a meaningful enhancement to the social economy better and social welfare. In this context, the outcomes of social service based on the increase of social economy product, revising social service system, upgrading social participation and outreach program, strengthening inner energy or self-financing of society, socializing society program whether through dissemination or article publication, it is related what has been stated by Unesco [27] on paper which entitled learning to be the World of Education to Day, and Tomorrow in Paris.

As a matter of fact that in UNG institution, the realization of social service increased reaching $10 \%$ each year, since 2014 until 2016, through some varied SKIMs or Programs that have been organized by Directorate of Social Service Division of Technology Research and Higher Education Ministry, in Indonesia, such as Science, Technology and Arts for Region 
(STA-R), STA for Society (STA-S), STA for Export (STA-E), STA for Superior Village Product (STA-SVP), STA for village partnership ( STA-VP) [28].

Sixthly, related to the students and alumni quality. As standardized Higher Education, the quality input of it should be guaranteed. UNG, as a Higher Education in Indonesia, has objectified, because the procedures of recruitment applied national procedures and mechanism standard [17]. Some varieties of activities that have been done related to student recruitment; such as increasing the students input; doing promotions by creating and distributing leaflet and brochures to the society as stake holders; then recruiting through national selection. Thus, in the academic process, UNG gives wellservice for the students in searching and acquiring knowledge, science and technology, by facilitating them with an excellent academic service, such as well-organized the quality of learning and teaching process; preparing well-management of learning facilities for examples: library, laboratory, ICT equipment; organizing the quality standard of administration management to support open and an equity access of UNG information. So, the learners can get the easiness and learning compatible in knitting their academic achievement. Strengthening, study programs quality, each of them executes visibly study to what competencies are needed and accordance with industry or the readiness employment. The result of that visibility or trace study is based on the curriculum construction (applying link and match approach), in order avoiding unemployment graduate. That's way in curriculum construction of Study Programs also accomplishing with entrepreneurship competency, as a reflecting quality assurance for guarantee stakeholders' satisfaction.

Seventhly, related the human resource quality; this standard is mostly determining the quality of institution, such as Study Program. So, upgrading qualification of human resources is one of the requirements for having a high quality performance of institution. Otherwise, a qualified human resources need to enrich their function in managing Study Program. UNG has a meaningful organizing management, as reflected in quality management policy, as matter of fact almost $40 \%$ averages in Study Programs of UNG having Doctoral or Ph.D. qualifications, while the rest $60 \%$ staff members of Study Program is master level. However being viewed from academic grade, from 600 UNG staff members, it is around 9 $\%$ Professor Level, associate Professor reach 65\%, and assistant Professor is around $21 \%$. We do not deny that the data is quiet dynamic improve from time to time. It seems that it has a strongly influence, to accelerate the Study Programs' accreditation; all most $99 \%$ of Study Programs done accreditation obtained minimally B mark. From that amount, it is around $80 \%$ Study Programs got B score, while $20 \%$ got A mark. However, before this period, it is around $45 \%$ of Study Programs got $\mathrm{C}$ mark. Fortunately, that accreditation score become quickly changed to be higher score; most of studies programs have acquired minimally score B, as what had stated previously.
Eigthly, related to the quality of budget plan, infrastructure, learning facilities, and information technology system. This quality standard is a competitive reference that supporting learning and teaching quality which its coverage consists of budget, facility, infrastructure, and information system management quality needed to actualize the SGU Vision, by implementing the mission in well management for achieving the UNG's and Study Programs' aims. That's way the healthy indicators of UNG organization can be counted from several dimensions. As represented data, those dimensions coverage: (a) Balances budget proportionally is showing in moderate level; supporting the realization of academic programs of UNG; (b) Having adequate infrastructure and educational facilities that supporting academic programs, especially learning and teaching process, such as laboratory, library, garage, experiment station; field trials; (c) Having enough facility and infrastructure management quality encompasses planning procurement, implementing programs, maintenance, updating, and documenting assets; (d) having an excellent Information Communication Technology management quality which coverage the input, process and output/outcomes of information technology and science supporting quality assurance implementation in all institution levels in UNG.

Ninthly, related to the institutions partnership or networking. Partnership programs are strengthening the fluency of three Higher Education Tasks implementation. In building up partnership, UNG applies the mutual benefit principle among the institutions that having made a network. So, Letter of Agreement noted what potentialities owned for each institution that might be shared, for acquiring the same aims. The networking items will be break down on the operational action called action plan in the detail of implementation programs. That's way in measuring the successful networking; UNG elaborates the successful indicators based on the action plan points that have been achieved, based on the program schedule. In observing the successful networking, UNG evaluate periodically and reflecting the programs of networking comprehensively based on the partnership institutions, and their programs schedule.

In creating the successful networking of an action plan, UNG had constructed the academic strategy police that to be a guide in implementing the partnership institution program. Based on the realistic data and information collected in UNG, each unit and Study Program get significant benefit from networking program dimension; as (a) human resource qualification and professionalism gradually improved, that effectively supporting the good governance implementation; (b) occurring well management of academic infrastructures and facilities more effectively and efficiently; (c) Intensively implementing research activities that promoting the science publication, including social services and outreach programs; (d) appearing some scientific activities in internal UNG and its institution partners not only in home country but also in foreign countries; (e ) Some sharing budgets are form the institution partners to fund the three tasks of Higher 
Education, such as collaborative research, social services or outreach programs and learning-teaching activities.

Realizing all quality assurance parameters such what have been elaborated on this research findings and discussion are available to support the cultural quality revitalization model in strengthening the Higher Education in creating its capacity building 'Good Learning Culture'.

\section{CONCLUSION}

This study concerns on how to improve the quality culture of academic staffs through the revitalization model created, in strengthening the Higher Education institution capacity building. The implementation of this study utilize Research and Development (R\&D) approach, so it is successful to formulate a model of revitalization quality culture base on conceptual and procedural model. Conceptual model is concerning to enlarge the human resources or staffs' insight towards some theoretical concepts and principles of quality paradigms in Higher Education. Procedural model concerning to a treatment of institution quality management by optimizing the role of management document, in reflecting and upgrading the academic quality.

To treat the cultural quality systematically as a 'Good learning Culture', this study successfully identified nine dimensions as quality paradigms. Those dimensions are a base of creating the planning, implementing, measuring and evaluating the quality parameters of Higher Education in strengthening its capacity building. The ninth of quality dimensions consist of: Managing vision, mission and goal of institution; organizing leadership and organization; Designing well curriculum, learning and teaching process; Improving research quality and publication; Enlarging the outreach of social service; Strengthening the students and alumni quality entering the competitive jobs industries; Building up staffs or human resources quality; Optimizing the quality budget plan, infrastructure, learning facilities and information system; Developing institution partnership and networking in supporting the Higher Education Institution performing its three academic tasks.

In the realization treatment, this study is successful to evoke the staffs' responsibility towards their academic quality, including quality institution management that can be reflected gradually on their culture and behavior. Furthermore the treatment of quality management documents had been prepared well, as base for accelerating the institution accreditation, and its units and departments.

Finally, this study has successfully created a model for building up cultural quality revitalization model in strengthening the institution capacity building as best practice 'Good Learning Culture'. This model can be improved and modified based on the future need, as a realization of principle sustainability or continuous improvement, as attaching in the following appendix of this paper.

\section{ACKNOWLEDGMENT}

In this occasion, the author would like to express an appreciation and thanks to the academic community of UNG for their cooperation in the implementation of this study. Thus, the author also addresses deep thanks to the Research Institution of Kemenristekdikti and UNG, that supporting and facilitating the implementation of this study at Universitas Negeri Gorontalo.

\section{REFERENCES}

[1] C. Searcy, S. Karapetrovic, dan D. McCartney, "REFLECTIVE PRACTICE Application of a systems approach to sustainable development performance measurement," hal. 182-198, 2007.

[2] F. C. Lunenburg, "Organizational Culture-Performance Relationships: Views of Excellence and Theory Z," Natl. Forum Educ. Adm. Superv. J., vol. 29, no. 4, hal. 1-10, 2011.

[3] E. ul Mujeeb dan Muhammad Shakil Ahmad, "Impact of Organizational Culture on Performance Management Practices in Pakistan,” Bus. Intell. J., vol. 7, no. 1, hal. 52-57, 2011.

[4] J. D. Ratnasari, M. Makmur, dan H. Ribawanto, "PENGEMBANGAN KAPASITAS (CAPACITY BUILDING) KELEMBAGAAN PADA BADAN KEPEGAWAIAN DAERAH KABUPATEN JOMBANG," J. Adm. Publik, vol. 1, no. 3, hal. 103$110,2013$.

[5] S. P. Robbins dan T. A. Judge, Organizational Behavior. United States of America: Prentice Hall, 2012.

[6] J. V. Saraph, P. G. Benson, dan R. G. Schroeder, “An Instrumen for Meansuring the Critical Factor of Quality Managemen," vol. 20, hal. 801-829, 1989.

[7] A. Jamal dan K. Anastasiadou, "Investigating the effects of service quality dimensions and expertise on loyalty," Eur. J. Mark., vol. 43, no. modelling approach and proposes a conceptual, hal. 398-420, 2009.

[8] A. Pertiwi, "Konsep Sistem OLTP pada Sistem Penjaminan Mutu Internal untuk Minimum Standar Nasional Pendidikan," ISTATEMENT STIMIK ESQ, vol. 2, no. Sistem Penjaminan Mutu Internal, hal. 13-23, 2016.

[9] M. F. Husein, Manajemen Strategik Berbasis AKreditasi PerguruanTinggi. Yogyakarta: Governa Training \& Consulting, 2012.

[10] D. Ulrich, W. Brockbank, A. K. Yeung, dan D. G. Lake, "Human Resource Competencies " An Empirical Assessment," vol. 34, no. 4, hal. 473-495, 1995.

[11] A. Sari, A. Firat, dan A. Karaduman, "Quality Assurance Issues in Higher Education Sectors of Developing Countries; Case of Northern Cyprus," Procedia - Soc. Behav. Sci., vol. 229, hal. 326334, 2016.

[12] S. Muhammad, "Kepemimpinan Dalam Sistem Penjaminan Mutu Pendidikan Tinggi," J. Ilm. WIDYA, vol. 2, no. 3, hal. 56-67, 2014.

[13] M. M. Hamad dan S. T. Hammadim, "Quality Assuraance Evaluation for Higher Education Institutions Using Statistical Models," Int. J. Database Manag. Syst. ( IJDMS ), vol. 3, no. 3, hal. 88-98, 2011.

[14] C. D. Glickman, Leadership for Learning. Alexandria, Virginia USA, 2002.

[15] S. L. Ahire, D. Y. Golhar, dan M. A. Waller, "Development and Validation of Tqm Constructs.," Decis. Sci. J., vol. 27, no. 1, hal. 2004, 1996.

[16] S. M. Allais, Quality assurance in education systems, vol. 20, no. 5. Braamfontein: Centre for Education Policy Development, 1994. 
[17] W. Ko dan F. Chung, "Teaching Quality, Learning Satisfaction , and Academic Performance among Hospitality Students in Taiwan,' World J. Educ., vol. 4, no. 5, hal. 11-20, 2014.

[18] J. Grifoll, The concept of excellence in higher education "Head of the Quality Assessment Department at the Catalan University Quality Assurance Agency (AQU Catalunya)," 20 ed. Brussels, Belgium: European Association for Quality Assurance in Higher Education AISBL 2014, Brussels ENQA, 2014.

[19] A. Amaral, "Quality Assurance and Assessment in Higher Education," Semin. - Oxford Learn. Inst. Oxford Univ., hal. 1-21, 2009.

[20] Arwildayanto, S. Achmad, dan S. Katili, "Unggulan perguruan tinggi," Gorontalo, 2013.

[21] S. Achmad, "Model Penerapan Kualifikasi Kurikulum Nasional Indonesia (KKNI) Sebagai Penguatan Mutu Program Studi Pariwisata dan Pendidikan Bahasa Inggris Bahasa Sastra dan Budaya Universitas Negeri Gorontalo," GORONTALO, 2014.

[22] C. S. Nair, P. Mertova, dan N. Murdoch, "Balancing Customer Needs and Standards in Higher Education 'An Integrated Approach to Quality Enhancement in a Multi-Campus University,"” Qual. Approaches High. Educ., vol. 3, no. 1, hal. 2-7, 2012.

[23] M. Kohiri, "Sistem Penjaminan Mutu Perguruan Tinggi Ditejn Dikti," Semin. Nas. VI SDM Teknol. Nukl., no. SISTEM PENJAMINAN MUTU PERGURUAN TINGGI, hal. 207-212, 2010

[24] D. Sukaningtyas, "Developing the Capacity of School Management to Build Understanding of Vision and Mission," vol. 14, hal. 53-58, 2016.

[25] S. Silverman, L. Tyson, dan J. Krampitz, "Teacher feedback and achievement in physical education: Interaction with student practice," Teach. Teach. Educ., vol. 8, no. 4, hal. 333-344, 1992.

[26] D. Waite, "Instructional supervision from a situational perspective," Teach. Teach. Educ., vol. 8, no. 4, hal. 319-332, 1992.

[27] E. Faure et al., Learning to be. The World of Education Today and Tomorrow. Paris: The United Nations Educational, Scientific and Cultural Organization, 1972.

[28] Direktorat Riset dan Pengabdian kepada Masyarakat, Direktorat Jenderal Penguatan Riset dan Pengembangan Kementerian Riset, Teknologi, Panduan pelaksanaan penelitian dan pengabdian kepada masyarakat di perguruan tinggi edisi ix, 10 ed. Jakarta, 2016. 
Appendix of Paper

\section{MODEL REVITALIZATION CULTURAL QUALITY DEVELOPMENT 'GOOD LEARNING CULTURE' IN HIGHER EDUCATION AS A RESEARCH TREATMENT}

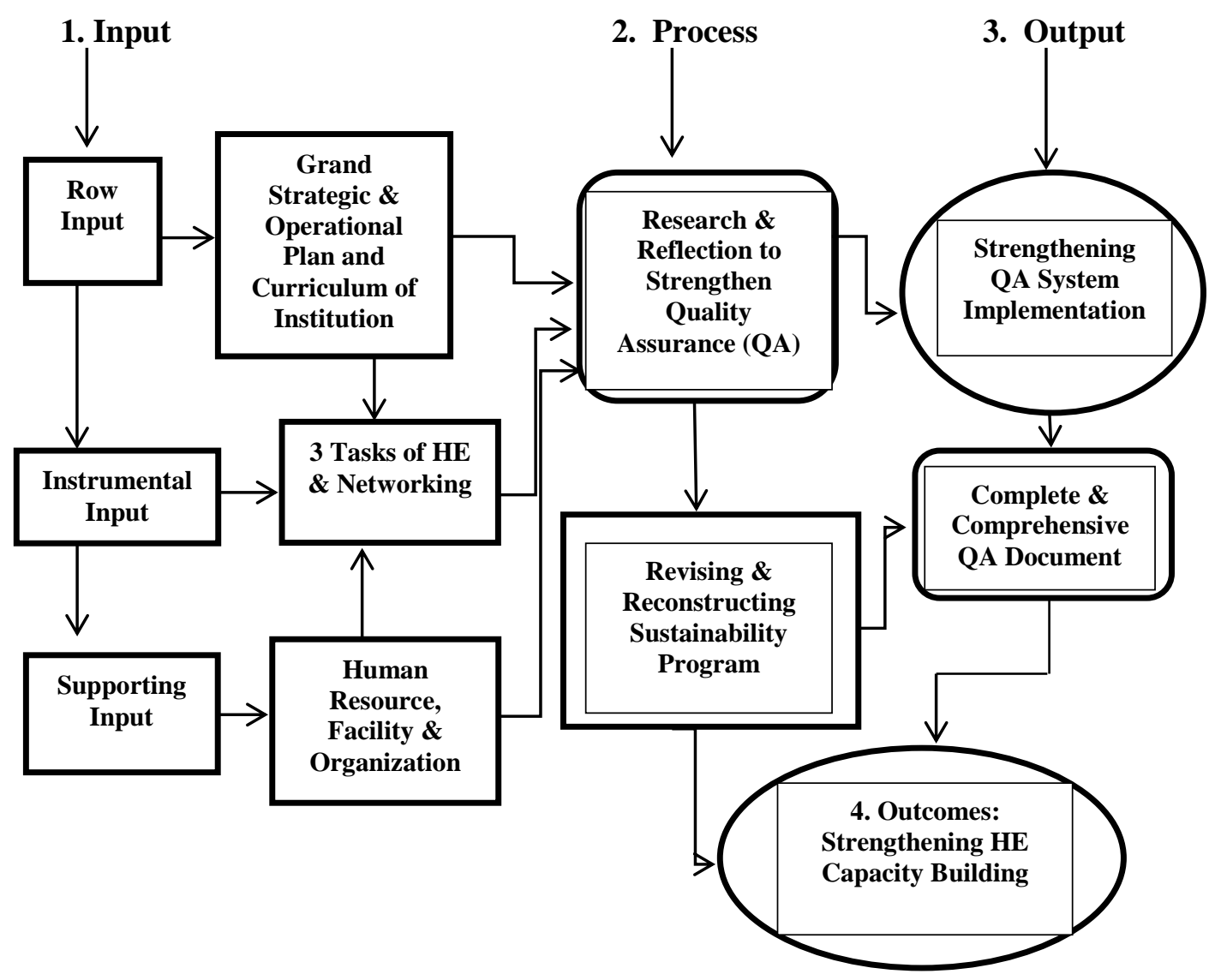

